resorbiert. Nur noch das Hämoglobineisen wird in ausreichenden Mengen aufgenommen. Von der Vermutung ausgehend, daß eine mangelhaft digestive Freisetzung des Myoglobin- bzw. Hämoglobineisens bei Gastrektomierten und einer Gruppe von Magen- $2 / 3^{-}$Resezierten vorliegt, wurde die verabreichte Nahrung mechanisch zerkleinert und mit einem Magenenzympräparat versehen vorverdaut.

Bei den bisher so untersuchten Patienten ergab sich eine wesentliche Verbesserung der Resorbierbarkeit des in vitro aufbereiteten Myoglobin- bzw. Hämoglobineisens, besonders bei Billroth I-Patienten.

\title{
279. Magensekretion nach Stimulation mit 15-Leucin-Humangastrin I
}

\author{
B. Konz*, F. HoLLE und E. WÜNSOH-München
}

\section{Gastric Secretion after Stimulation with 15-Leucine-Human Gastrin I}

Summary. By means of a new method of synthesis Wünsch and Deimer (1970) succeeded in producing pure, biologically highly active, chemically stable 15-leucine human gastrin I. The effect of this substance on gastric secretion was tested in 50 patients with duodenal ulcer before and after selective proximal vagotomy with pyloroplasty and in subjects with healthy stomachs. 80 analyses of gastric secretion are described, obtained after varying administration and dosage of gastrin. In 20 patients with duodenal ulcer there was after s. p. v. with pyloroplasty a reduction of ca. $80 \%$ in gastric secretion stimulated with 15-leucine human gastrin I. In 10 patients pentagastrin tests (Gastrodiagnost) as well as tests with 15-leucine human gastrin I were performed, showing a significantly higher stimulant effect of the latter. Stimulation with different doses shows that maximal acid secretion can be obtained with ca. $0.001 \mathrm{mg}$ gastrin $/ \mathrm{kg} \mathrm{h}$. This new synthetic gastrin must be regarded as a test substance distinctly superior to the usual stimulants with regard to maximal acid stimulation.

Zusammenfassung. Auf Grund eines neuen Syntheseweges gelang Wünsch u. Deimer (1970) die Reindarstellung des biologisch hochaktiven, chemisch stabilen 15-Leucin-Humangastrin I. Die Wirkung dieser Substanz auf die Magensekretion wurde bei 50 Patienten mit Uleus duodeni vor und nach selektiver proximaler Vagotomie des Magens mit Pyloroplastik und bei magengesunden Personen überprüft. 80 Magensekretionsanalysen werden dargestellt, die nach unterschiedlicher Applikation und Dosierung von Gastrin erhalten wurden. Bei 20 Patienten mit Ulcus duodeni fand sich nach $\mathrm{SpV}$ mit Pyloroplastik eine Reduktion der mit 15-Leucin-Humangastrin I stimulierten Magensekretion von ca. 80\%. Bei $10 \mathrm{~Pa}$ tienten wurden sowohl Pentagastrin-Teste (Gastrodiagnost) als auch Teste mit 15-Leucin-Humangastrin I durchgeführt, die einen signifikant höheren stimulatorischen Effekt von 15-Leucin-Humangastrin I zeigten. Die Stimulation mit unterschiedlichen Dosierungen ergibt, daß mit ca. $0,001 \mathrm{mg}$ Gastrin $/ \mathrm{kg} / \mathrm{h}$ eine maximale Säuresekretion erzielt werden kann. Dieses neue synthetische Gastrin ist als eine den üblichen Stimulantien hinsichtlich der maximalen Säurestimulation deutlich überlegene Testsubstanz aufzufassen. 